\title{
EMBRYONIC AND LARVAL DEVELOPMENT OF A RED STRAIN OF THE EGYPTIAN AFRICAN CATFISH (Clarias gariepinus Burchell, 1822)
}

\author{
Bambang Iswanto ${ }^{\#}$ Imron, Rommy Suprapto, and Huria Marnis \\ Research Institute for Fish Breeding \\ (Received 17 June 2014; Final revised 3 June 2015; Accepted 8 June 2015)
}

\begin{abstract}
Egyptian African catfish is one of several African catfish (Clarias gariepinus) strains introduced to Indonesia. Several breeding activities using that strain in Sukamandi resulted in some individuals with redish-yellow body colour (a red strain). Biological informations related to aquacultural aspects of that red strain were still scarce. The present study aimed to elucidate the embryonic and larval developments of the red strain compared to those of the black (normal coloured) one, using the progenies obtained from artificial spawning of each red and black coloured brooders. Results of the present study revealed that embryonic developments of the red and black strains were similar. Their larval development were also quite similar, however, both larvae could be distinguished based on the pigmentation. The red strain larvae were golden-red-yellowish in colour, while the black strain larvae were greyish covered with dense melanophores. Total length of the red strain larvae tended to be lower than those of the black strain.
\end{abstract}

KEYWORDS: embryo, larva, development, red strain, Egyptian African catfish (Clarias gariepinus)

\section{INTRODUCTION}

African catfish (Clarias gariepinus Burchell, 1822) has already became one of the economically important cultured fish species in Indonesia. Several strains of the African catfish were introduced for aquacultural purposes to Indonesia. One of them was the Egyptian strain, introduced to Indonesia in 2007. Research Institute for Freshwater Fish Breeding and Aquaculture Technology (presently Research Institute for Fish Breeding) Sukamandi has collected the Egyptian African catfish since 2010. Body colour of the collected Egyptian African catfish was black (normal). However, several breeding activities using that strain in 2011 resulted in some progenies with reddish-yellow coloured body (then were named here in as a red strain of Egyptian African catfish).

In South Africa, a red strain (in some publications were also referred to golden strain) obtained from normal coloured brooders of African catfish $C$. gariepinus also occurred, and its catchability, growth of juveniles, cannibalism at larval and juvenile stages, fecundity, proximate, fatty acid, amino acid, minerals, and composition of the muscle compared to those

\# Corresponding: Research Institute for Fish Breeding Jl. Raya Sukamandi No. 2, Subang 41256, West Java, Indonesia. Tel.: + (0260) 520500

E-mail: bambang.is031@kkp.go.id of the normal coloured one have been reported (Prinsloo \& Schoonbee, 1989; Prinsloo et al., 1989a; 1989b; 1990; Hoffman \& Prinsloo, 1995; Hoffman et al., 1995a; 1995b). Results of those studies suggested that performances of the red strain was different from those of the normal coloured one. On the other hand, considerable intraspecific morphological variations on C. gariepinus strains in Africa have been reported, and the Egyptian strain was morphometrically different from other strains (Teugels, 1998; Rognon et al., 1998). Therefore, exploration on biological informations of the introduced Egyptian African catfish and evaluation on its potentialities for aquaculture in Indonesia were needed. Those informations were also needed for the red strain one. Results of those comparative studies would be beneficial in justifying whether that strain would be favourable for aquaculture purposes.

Some comparative studies of both red and black (normal coloured) strains of the Egyptian African catfish have been conducted, including larval and juvenile growth performances, length-weight relationship and condition factor analysis (Bambang et al., 2013a; b; c), and the results suggested that performances of both strains were different. Another important biological aspect related to aquaculture activities was the knowledge on embryonic and larval development. Those informations were useful to allow better 
larviculture management. The present study was conducted to elucidate embryonic and larval developments of the red strain of Egyptian African catfish compared to those of the black one. While embryonic and larval development of the normal coloured C. gariepinus have already been reported by several workers (Legendre \& Teugels, 1991; Matsumoto et al., 2001; Sule et al., 2001; Mukai et al., 2008; Osman et al., 2008; Kipper et al., 2013; Olaniyi \& Omitogun, 2013), there was no report for those of the red coloured $C$. gariepinus.

\section{MATERIALS AND METHODS}

Definition of embryonic and larval developments in the present study following the definition given by Adriaens (1998) for C. gariepinus. Embryo stages corresponded to the developmental processes within period between fertilization until hatching. While, larva was period of the developmental processes from hatching to the end of metamorphosis, i.e. when the medial fin fold were completely differentiated into true dorsal and anal fins with fin rays, and the disappearance of fin fold rudiments around the caudal fin.

The present study was held in the Clarias catfish research hatchery of the Research Institute for Fish Breeding (RIFB) Sukamandi on April 2012. Embryo and larvae of the red strain were obtained through the artificial breeding of the mutant red coloured brooders (inbreeding). As a comparison, at the same time, the normal (black) coloured brooders were also artificially bred. Those all thirteen months old brooders were the progenies of the normal coloured brooders collected in 2010. Three pairs of each red and black coloured brooders were induced using a commercial synthethic hormone (ovaprim, Syndell Laboratories Inc., Canada) at the dose of $0.1 \mathrm{~mL} / \mathrm{kg}$ body weight of the brooders. Sperm of male brooders were macerated seven hours after hormonally induced. Sperm from three males of each red and black male brooders were pooled, diluted with $0.9 \% \mathrm{NaCl}$ (PT Widatra Bhakti, Pasuruan), then stored in closed bottles. After that, eggs were collected by stripping of the readily stripped females brooders. Approximately 0.2 g eggs of each female brooder was placed into transparent plastic baskets, then fertilized with the pooled sperm. Fertilization process was were activated using mineral drinking water (AQUA, PT Tirta Investama, Bogor). Those mineral drinking water of $500 \mathrm{~mL}$ volume were also used as egg's incubation media within the transparent plastic baskets. Observations of the embryonic development were conducted continously from the moment of fertilization until hatching using a stereoscopic microscope (Nikon SMZ-745T, Nikon Instruments Inc., USA) equipped with an ocu- lar micrometer (KS, Tokyo, Japan). Stages of each embryonic developmental progress were photographed using a digital camera (Nikon CoolPix L12, Nikon Corp., Japan).

For larval development observations, 100 newly hatched larvae of each red and black brooders were maintained in the transparent plastic baskets filled with one liter of mineral drinking waters. Observations of the larval development were conducted by taking randomly 30 larvae, placed into petridish with a few drops of water. Observation and documentation of the larval development until their morphology resembled the adults were facilitated by a stereoscopic microscope equipped with a digital camera and an ocular micrometer, as used in the observations of the embryonic development.

When active open-close movements of the larval mouth were observed, the Artemia sp. (Supreme, Golden West, USA) nauplii were offered to the larvae. At the third day of feeding, those nauplii then were replaced with silkworms (Tubifex sp.), and then were gradually replaced with finest-sized commercial dry feed containing $40 \%$ of crude protein (HI-PROVITE PS-P and BINTANG 581, PT Centralproteina Prima, Mojokerto). Those feeds were given ad libitum four times daily (in the early morning, midday, late afternoon and in the evening).

\section{RESULTS AND DISCUSSION}

\section{Embryonic Development}

Mature intraovarian oocytes of the red strain of Egyptian African catfish used in artificial fertilization in the present study were in relatively spherical shape, adhered to each others, brownish-yellow in colour, with reddish coloured nucleus in the central position (Figure 1A), similar to those of the black strain one. Oocyte diameter ranged 1.29-1.39 mm (averaged 1.34 $\pm 0.03 \mathrm{~mm}$ ), relatively similar to those of the black strain (ranged 1.29-1.42 mm, 1.35 $\pm 0.04 \mathrm{~mm}$ in average). Ovulated (stripped) oocytes of the red, as well as the black, strain of Egyptian African catfish were more or less oval in shape, looked flattened, brownish-yellow in colour, translucent, with germinal part at the one side (animal pole) appeared reddish-brown in colour and darker than the opposite parts (Figure 1B). The oval shape of those ovulated oocytes of the Egyptian African catfish corresponded to the oocytes shape of other $C$. gariepinus strains reported (Riehl \& Appelbaum, 1991; Mekkawy \& Osman, 2006; Olaniyi \& Omitogun, 2013). The colour of ovulated oocytes of other African catfish C. gariepinus was reported to be slightly varied. The greenish-yellow colour of ovulated oocytes from $C$. gariepinus in Israel was reported 
by Riehl \& Appelbaum (1991). Olaniyi \& Omitogun (2013) working with C. gariepinus in Nigeria found slightly differences, some of female brooders possessed deeply greenish with faint brownish coloured oocytes, while in some other female brooders were faintly greenish and deeply brownish in colour. Omeji et al. (2013) also found golden coloured oocytes from local $C$. gariepinus and greenish one from the exotic strain in Nigeria. In the present study, the colour of ovulated oocytes from all of female brooders of the Egyptian African catfish strain was brownish-yellow, whereas, eggs of other collected strains in RIFB Sukamandi had various colour, from greyish-green to pale brown (unpublished data). Those colour differences might be due to strain (strain specific), as was also suggested by Osman et al. (2008) and Olaniyi \& Omitogun (2013).

Diameter of the ovulated oocytes stripped from the red strain of Egyptian African catfish along the longest axis ranged $1.29-1.45 \mathrm{~mm}(1.37 \pm 0.05 \mathrm{~mm}$ in average), relatively similar to those of the black strain (ranged 1.29-1.45, averaged $1.39 \pm 0.06 \mathrm{~mm}$ ). Diameter of ovulated oocytes in other strains of the African catfish $C$. gariepinus were slightly different. Diameter of ovulated oocytes in C. gariepinus in Israel averaged $1.5 \mathrm{~mm}$ (Riehl \& Appelbaum, 1991), in Indonesia averaged $1.72 \mathrm{~mm}$ (Lenormand et al., 1998), in Nigeria ranged 0,8-1,2 mm (Sule et al., 2001) and $1.0 \pm 0.1 \mathrm{~mm}$ (Olaniyi \& Omitogun, 2013) and in the Netherlands ranged 1.3-1.6 mm (Osman et al., 2008). Slightly differences of those ovulated oocytes diameter might be related to the differences on their origin (strain, history of domestication and/or culture), condition, age, size and food supply during oogenesis (reviewed by Kamler, 2005). Those ovulated oocytes diameter in African catfish C. gariepinus were more or less similar to that of other African Clariid catfish species, which about $1 \mathrm{~mm}$ in $C$. anguillaris (Onyia et al., 2012), averaged $1.54 \pm 0.04 \mathrm{~mm}$ in Heterobranchus longifilis (Legendre, 1986) and ranged 1.6$1.7 \mathrm{~mm}$ in H. bidorsalis (Adebayo \& Fagbenro, 2004). Asian Clariid catfish species had also similar or slightly bigger sizes than those of African catfish. Diameter of ovulated oocytes from C. batrachus in Malaysia ranged 0.99-1.27 $\mathrm{mm}$ (Cheah et al., 1990), and in Indonesia averaged $1.28 \mathrm{~mm}$ (Lenormand et al., 1998). Diameter of ovulated oocytes from C. macrocephalus in Malaysia ranged 1.301-1.472 mm (Mollah \& Tan, 1983), whereas in the Philippines ranged 1.2-1.6 mm (Tan-Fermin, 2003). For C. meladerma in Indonesia, it was bigger, averaged $2.08 \mathrm{~mm}$ (Lenormand et al., 1998). Ovulated oocytes diameter of Heteropneustes fossilis in India ranged 1.1-1.2 mm (Puvaneswari et al., 2009). Adriaens \& Vandewalle (2003) reviewed that oocytes diameter of Clariid catfishes were smaller than those of other Siluriformes (catfish) species.

A while after fertilization, egg hydration (water hardened egg) occurred, forming perivitelline space, separated the yolk from egg membrane and the shape of eggs, including the yolk, became more spherical, and the egg diameter increased to $1.39-1.52 \mathrm{~mm}$ (1.47 $\pm 0.03 \mathrm{~mm}$ in average) for both red and black strain of the Egyptian African catfish. After contact with water, eggs of the red strain, as well as the black strain became more yellowish in colour, with reddish germinal part at the animal pole, and the egg surface forming a sticky mass adhered one side of the egg surface to the substrata (Figure 1C). Those sticky mass appeared to consist of whitish filaments attached one side of the egg surface to the substrata. Those filament apparatus responsible for egg adhesiveness in C. gariepinus, according to Riehl \& Appelbaum (1991) were a part of zona radiata, and the shape was unique among other apparatus of Teleostei (reviewed by Riehl \& Patzner, 1998; Mekkawy \& Osman, 2006), because when viewed from a lateral side, the fertilized eggs appeared as a fur cap. Similar egg attachment system was reported in $H$. longifilis (Legendre \& Teugels, 1991). Eggs of other Clariidae and many other catfishes (Siluriformes) were also reported to be sticky in nature and adhered to substrata with several other methods (reviewed by Legendre et al., 1996; Riehl \& Patzner, 1998; Adriaens \& Vandewalle, 2003).
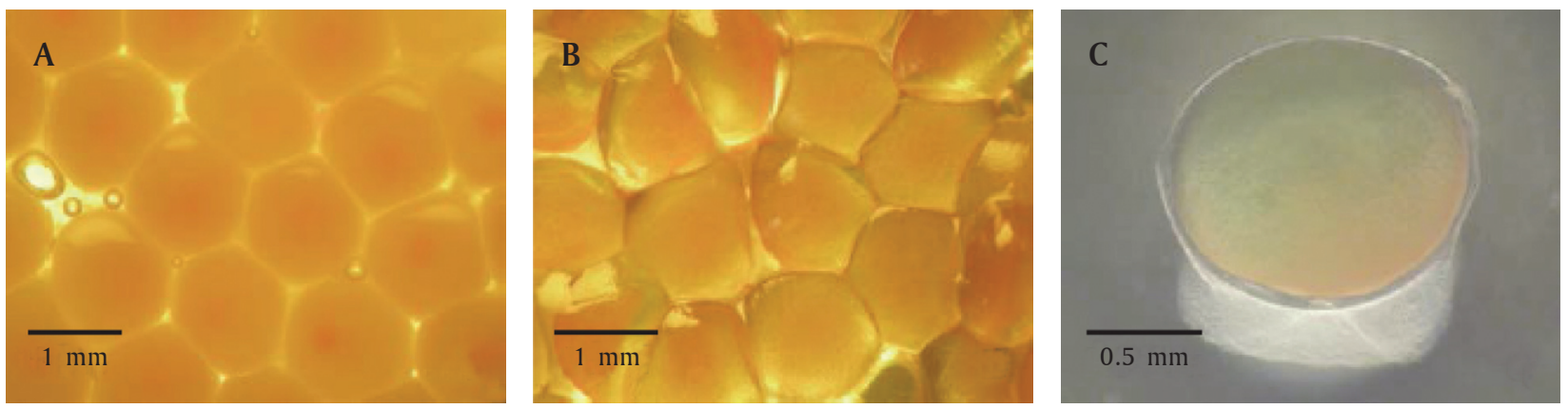

Figure 1. Intraovarian oocytes (A), ovulated oocytes (B) and fertilized egg of the Egyptian African catfish with a sticky mass adhered the one of egg surface to substratum (the surface of petridish) (C) 
Fertilized eggs of red and black strains of the Egyptian African catfish developed into embryonic developmental stage. Based on the observations conducted in the present study, both red and black strains exhibited a similar embryonic development. Several significant embryonic developmental processes until hatching at the incubation temperature of $27.0^{\circ} \mathrm{C}$ $29.5^{\circ} \mathrm{C}$ were presented in Table 1 and Figure 2. Eggs diameter of the red and black strains of Egyptian African catfish during embryonic developmental stages were relatively constant, ranged $1.39-1.52 \mathrm{~mm}$, as in after contact with water (water hardened eggs).

In general, embryonic development of Egyptian African catfish (either red or black strains) was relatively similar to that of other Siluriformes species (reviewed by Adriaens \& Vandewalle, 2003). Likewise, embryonic development of the red strain of Egyptian African catfish was similar to that of the black strain, as well as, similar to that of other African catfish

Table 1. Embryonic development of the Egyptian African catfish at the incubation temperature of $27.0^{\circ} \mathrm{C}$ $29.5^{\circ} \mathrm{C}$

\begin{tabular}{|c|c|c|}
\hline Stages & $\begin{array}{l}\text { Initial time } \\
\text { (minutes after fertilization) }\end{array}$ & Descriptions \\
\hline $\begin{array}{l}\text { Blastodisc } \\
\text { formation }\end{array}$ & 20 & $\begin{array}{l}\text { A large blastodisc appeared at the one side (germinal part, animal } \\
\text { pole) of the egg, apparent as a reddish coloured mass, denser than } \\
\text { other yolk parts, for which were still greenish and translucent } \\
\text { (Figure 2A) }\end{array}$ \\
\hline Two cells & 30 & $\begin{array}{l}\text { The first mitotic division of the blastodisc resulted in two similar } \\
\text { cells (Figure 2B) }\end{array}$ \\
\hline Four cells & 40 & Mitotic division of both cells resulted in four similar cells (Figure 2C) \\
\hline Eight cells & 50 & $\begin{array}{l}\text { Mitotic division of the four cells resulted in relatively similar eight } \\
\text { cells arranged in two rows of four cells (Figure 2D) }\end{array}$ \\
\hline Sixteen cells & 60 & $\begin{array}{l}\text { Mitotic division of the eight cells resulted in sixteen cells with more } \\
\text { irregular shape (Figure 2E) }\end{array}$ \\
\hline Morula & 65 & $\begin{array}{l}\text { The subsequent mitotic cell divisions occurred continously resulted } \\
\text { in blastomeres consisted of numerous small-sized cells (multi- } \\
\text { cellular) (Figure 2F) in the mulberry-like forms (morula), apparent } \\
\text { reddish and denser than the yolk mass, for which still greenish and } \\
\text { translucent (Figure 2G). Peristaltic wave (Figure 3) and free rotation } \\
\text { movements observed }\end{array}$ \\
\hline Blastula & 150 & $\begin{array}{l}\text { Assigned by the yolk invassion forming germinal ring, the egg yolk } \\
\text { were partially still uncovered by blastomeres (blastoderm) (Figure } \\
2 \mathrm{H} \text { ) }\end{array}$ \\
\hline Gastrula & 160 & $\begin{array}{l}\text { Assigned by the extending of blastoderm closure and covering the } \\
\text { yolk mass towards blastopore (the blastopore closure) (Figure 2I-L) }\end{array}$ \\
\hline $\begin{array}{l}\text { Somite } \\
\text { formation }\end{array}$ & 280 & $\begin{array}{l}\text { Condensation of blastoderm, in line with gastrula stage, occurred } \\
\text { when yolk mass were partially covered by blastoderm (Figure } 2 \mathrm{~J} \text { ). } \\
\text { Condensation of blastoderm was the early process of the formations } \\
\text { of head, body and tail buds, which appeared clearly in line with the } \\
\text { yolk mass covering (Figure } 2 \mathrm{~K}-\mathrm{L} \text { ), then elongated forming somites } \\
\text { (vertebral) column and the embryo appeared as C shape (Figure 2M) }\end{array}$ \\
\hline Organogenesis & 500 & $\begin{array}{l}\text { Head and tail buds formed, encircled the yolk, then elongated, } \\
\text { separated from the yolk, tip of the tail extended reaching to the } \\
\text { head (Figure } 2 \mathrm{~N}-\mathrm{P}) \text {. Embryo movements and heart beating commenc } \\
\text { ed respectively } 840 \text { and } 860 \text { minutes after fertilization, then more } \\
\text { frequent prior to hatching. Embryo size increased, thus almost filled } \\
\text { the whole egg space }\end{array}$ \\
\hline Hatching & 1,010 and 1,080 & $\begin{array}{l}\text { Larvae of the red strain (Figure } 2 \mathrm{Q} \text { ) hatched earlier than the black } \\
\text { one (Figure } 2 \mathrm{R} \text { ) }\end{array}$ \\
\hline
\end{tabular}



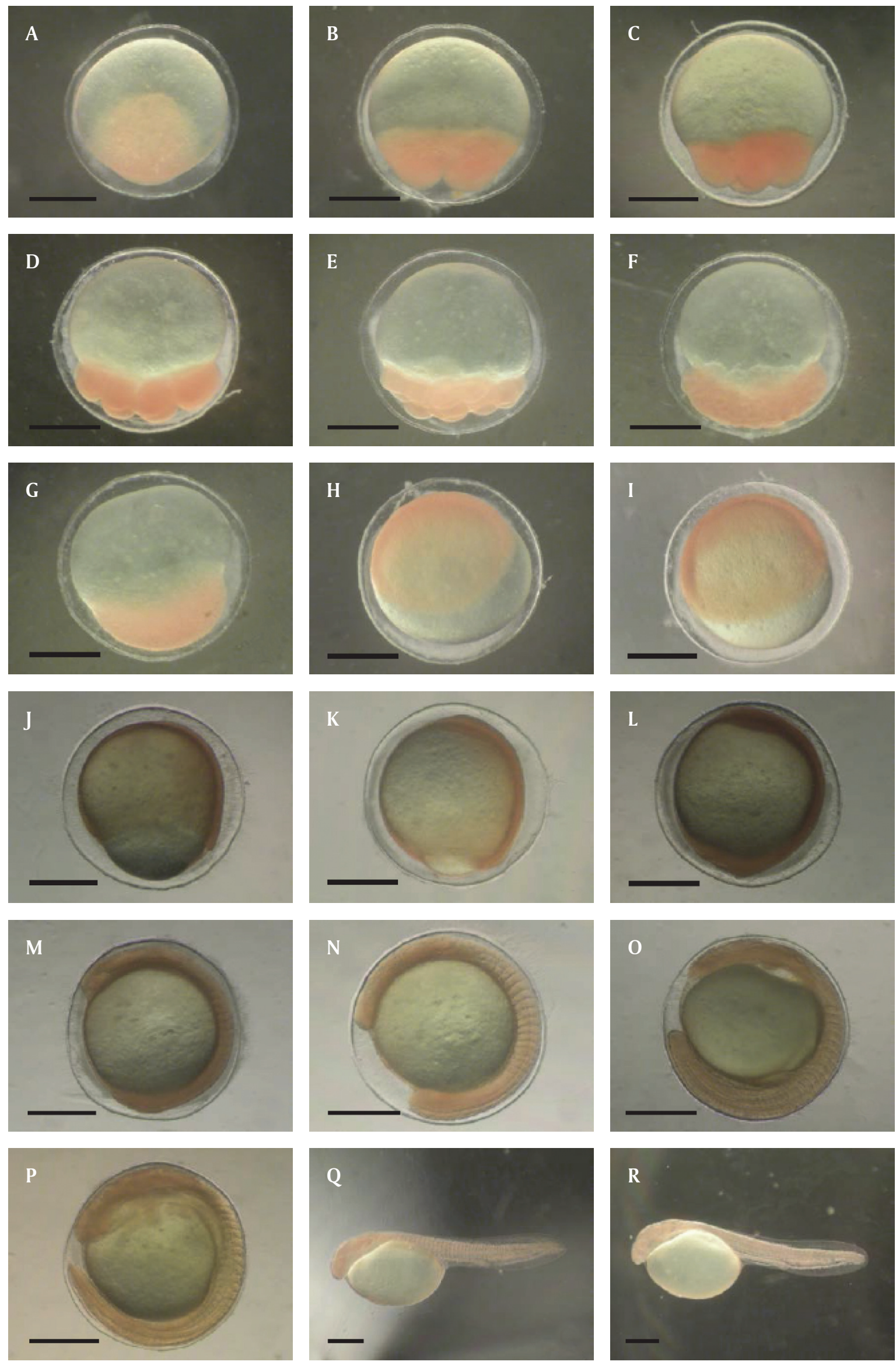

Figure 2. Embryonic development (A-P) and a newly hatched larva of red $(\mathrm{Q})$ and black $(\mathrm{R})$ strains of the Egyptian African catfish (scale bars $=0.5 \mathrm{~mm}$ ) 
strains reported in the other studies (Legendre \& Teugels, 1991; Sule et al., 2001; Mukai et al., 2008; Osman et al., 2008; Kipper et al., 2013; Olaniyi \& Omitogun, 2013). However, periods of the embryonic development of those $C$. gariepinus strains were slightly different. In Nigeria, the hatching commenced at 22 hours after fertilization at water temperature of $25.1^{\circ} \mathrm{C}$ (Sule et al., 2001), while at water temperature of $28.5 \pm 0.5^{\circ} \mathrm{C}$ commenced at 17 hours and 20 minutes after fertilization (Olaniyi \& Omitogun, 2013). Hatching of $C$. gariepinus in the Netherlands at water temperature of $24^{\circ} \mathrm{C}$ occurred at 40 hours after fertilization (Osman et al., 2008). In Brazil, the hatching occurred after approximately 30 hours of incubation at water temperature of $25^{\circ} \mathrm{C}$ (Kipper et al., 2013). Those differences were influenced by the water temperature, the higher the water temperature, the earlier the hatching taken place, as reported by Hogendoorn \& Vismans (1980), Kamler et al. (1994), Haylor \& Mollah (1995) and Oyelese (2006), and as reported by Legendre \& Teugels (1991) in $H$. longifilis and Dhara \& Saha (2013) for C. batrachus.

Based on the microscopic observation in the present study, peristaltic wave movement of the yolk surface of Egyptian African catfish observed in the embryonic developmental stage since 128 cells stage, initiated at 80 minutes after fertilization. Afterwards, free rotation movement of the yolk (including the blastomeres) within the perivitelline space commenced at 140 minutes after fertilization. Olaniyi \& Omitogun (2013) also observed those movements. However, they observed that those occurred at the gastrula stage, differed from the results of present study, which commenced at the morula stage, then ended at the late gastrula stage. Those peristaltic wave movement of yolk surface and the rotation of the yolk were also reported in other catfishes, e.g. in $H$. longifilis (Clariidae) (Legendre \& Teugels, 1991), in Pelteobagrus fulvidraco (Bagridae) (Wang et al., 2006) and in H. fossilis (Heteropneustidae) (KorzeleckaOrkisz et al., 2010).
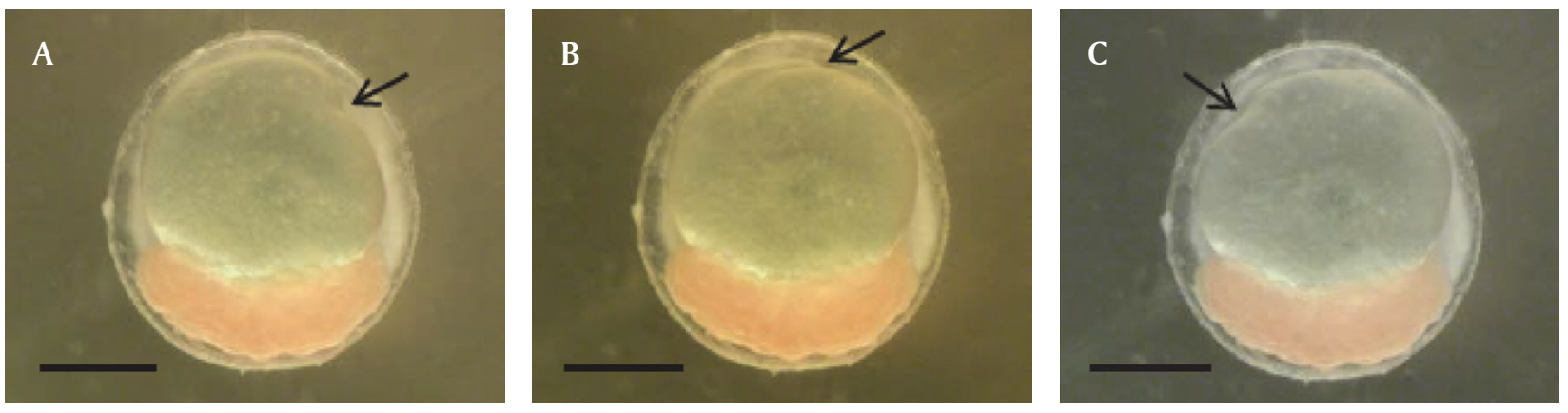

Figure 3. Peristaltic wave movements of the yolk mass surface at vegetal pole of the Egyptian African catfish egg. Arrows indicated the anticlockwise direction $(A, B, C)$ of the concave surfaces of the yolk mass (scale bars $=0.5 \mathrm{~mm}$ )

\section{Larval Development}

Morphological development of the red and black strains larvae of Egyptian African catfish at the water temperature of $27^{\circ} \mathrm{C}-31^{\circ} \mathrm{C}$ was photographed as presented in Figure 4 and 5. In general, larval development of the red strain of Egyptian African catfish was similar to that of the black strain, as well as of other African catfish strains (Legendre \& Teugels, 1991; Matsumoto et al., 2001; Sule et al., 2001; Mukai et al., 2008; Osman et al., 2008; Kipper et al., 2013; Olaniyi \& Omitogun, 2013). However, there were slightly differences in the timing related to the chronological development of those reported $C$. gariepinus larvae. Those might be as the results of the differences on the strain used, environment, mainly water temperature, or the observation accuracy and precision, especially in the recognition of the initiation process of the organs formation.

Total length of newly hatched larvae of the red strain ranged 3.05-3.58 mm (averaged 3.32 \pm 0.16 $\mathrm{mm}$ ), while those of the black strain were longer, ranged $3.53-3.97 \mathrm{~mm}$ (3.73 $\pm 0.16 \mathrm{~mm}$ in average). Morphological characteristics of both newly hatched larvae were similar, lacking pigmentations, and the colour of the body was golden-yellow and translucent. Their yolk sac were greenish in colour and transparent, with $0.80 \pm 0.31 \mathrm{~mm}^{3}$ of volume in the red strain, while in the black strain were $0.69 \pm 0.17 \mathrm{~mm}^{3}$. The only fin as locomotion movement organ was undifferentiated caudal fin fold. Their mouth have not been formed, and the head was stuck to the yolk sac. Digestive tract appeared as a short tube (alimentary canal) from posterior part of the yolk sac to the base of anal fin fold (Figure 4A and 5A).

Two hour after hatching, the head was not stuck to the yolk sac. Otocyst was observed, containing two otoliths. The yolk sac was equipped with an adhesive organ at the ventral part, which becames sticky, thus, almost all of the larvae were stuck each other on their ventral part of the yolk sac or attached to 
the substrata. The larvae were negatively phototaxis, accumulated in the darker areas. At five hour after hatching, mouth of the larvae began to differentiate, lower jaw (mandibular) bud appeared, attached to the yolk sac, but that mouth was apparently still without esophagus. Operculum and gill arches also formed (Figure $4 \mathrm{~B}$ and $5 \mathrm{~B})$.

A pair of primary (outter) mandibular barbels formed at six hours after hatching. Pigmentation of the eyes occurred seven hours after hatching, appeared blackish in colour for the black strain larvae, while in the red strain larvae were brownish. Up to twelve hours old, both red and black strain larvae had similar morphological appearances, except for the pigmentation. Initiated at six hours after hatching, pigmentations appeared at the head parts, around the eyes, anterior parts of the body and posterior parts of the yolk sac of the black strain larvae, appeared as sparse black small dots (Figure 5C). While, those pigments were absent in the red strain larvae (Figure $4 C)$. Body of the red strain larvae began to appear as golden-yellow in colour with golden-yellow coloured yolk sac, while the black strain larvae appeared as greyish in colour and transparent with yellowish-green coloured yolk sac. Those pigmentations became more obvious with increasing the ages. Nasal barbels, secondary (inner) mandibular barbels, maxillary barbels, and esophagus formed twelve hours after hatching. At eighteen hours after hatching, the movement of mouth and gill operculum commenced, and the stomach was formed, appeared as a yellowish sac (Figure $4 \mathrm{D}$ and 5D).

Active open-close movement of the mouth observed since 21 hours after hatching, but the larvae were still irresponsive to Artemia sp. nauplii offered. The red strain larvae began to consume the nauplii given at forty hours after hatching, while the black strain larvae at 42 hours after hatching. Yolk sac volume when the larvae started to consume the nauplii was difficult to be measured, however was not fully absorbed yet. In the present study, the yolk sacs were completely absorbed at about 66 hours after hatching. Mauguit et al. (2010) reported that absorption of the yolk sac in $C$. gariepinus larvae in Belgium were complete by sixty hours after hatching at the water temperature of $25^{\circ} \mathrm{C}-28^{\circ} \mathrm{C}$. While, in Nigeria was reported at 83 hours after hatching at water temperature of $28.5 \pm 0.5^{\circ} \mathrm{C}$ (Olaniyi \& Omitogun, 2013). On the other hand, Matsumoto et al. (2001) reported that complete yolk sac absorption of $C$. gariepinus in Malawi at water temperature of $22^{\circ} \mathrm{C}-25^{\circ} \mathrm{C}$ was observed at 166 hours after hatching, although about 98\% was absorbed by 100 hours after hatching. Those yolk sac absorptions were related to the water temperature,
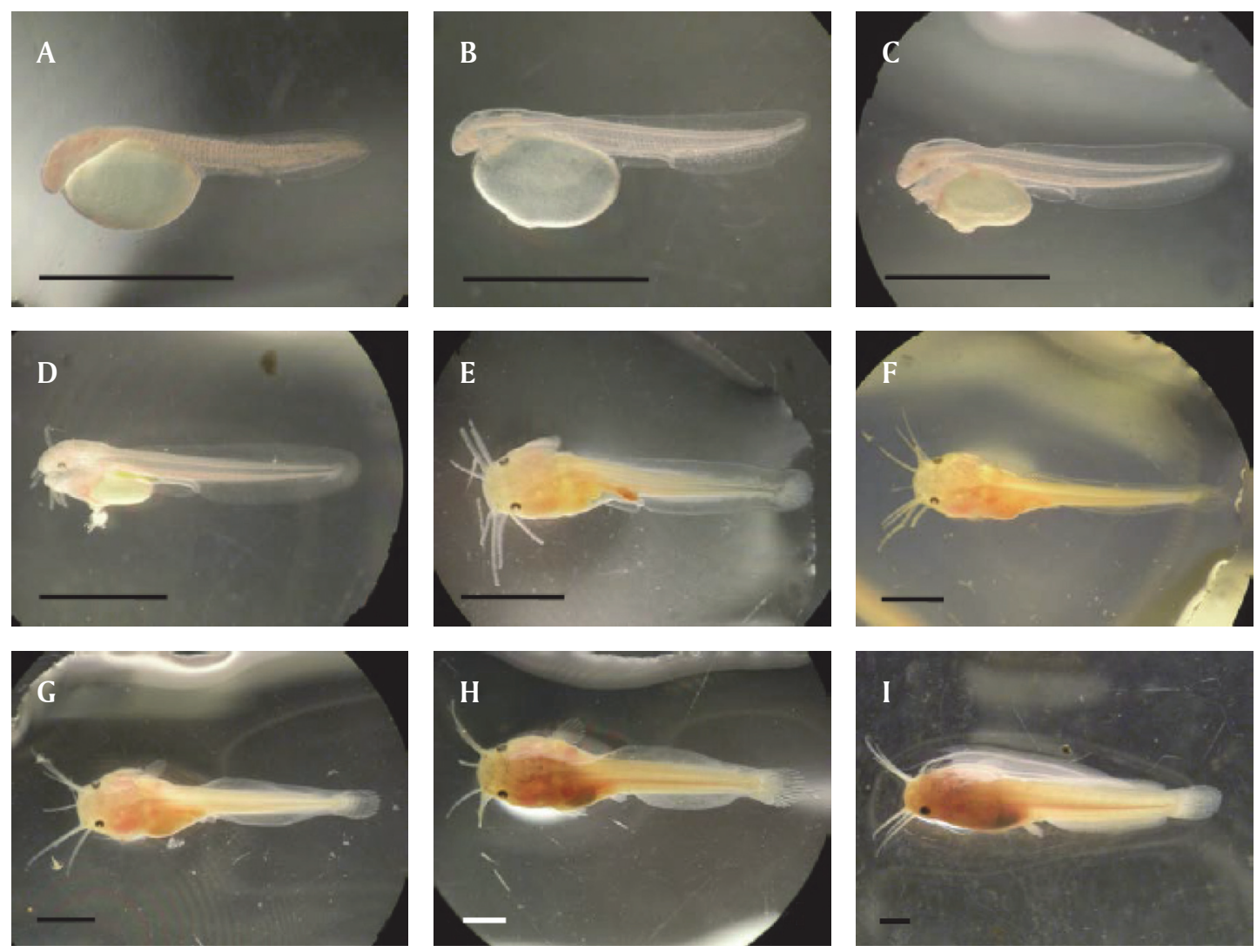

Figure 4. Larval development of the red strain of Egyptian African catfish from hatching until resembled the adults (20 days old) (scale bars $=2 \mathrm{~mm}$ ) 

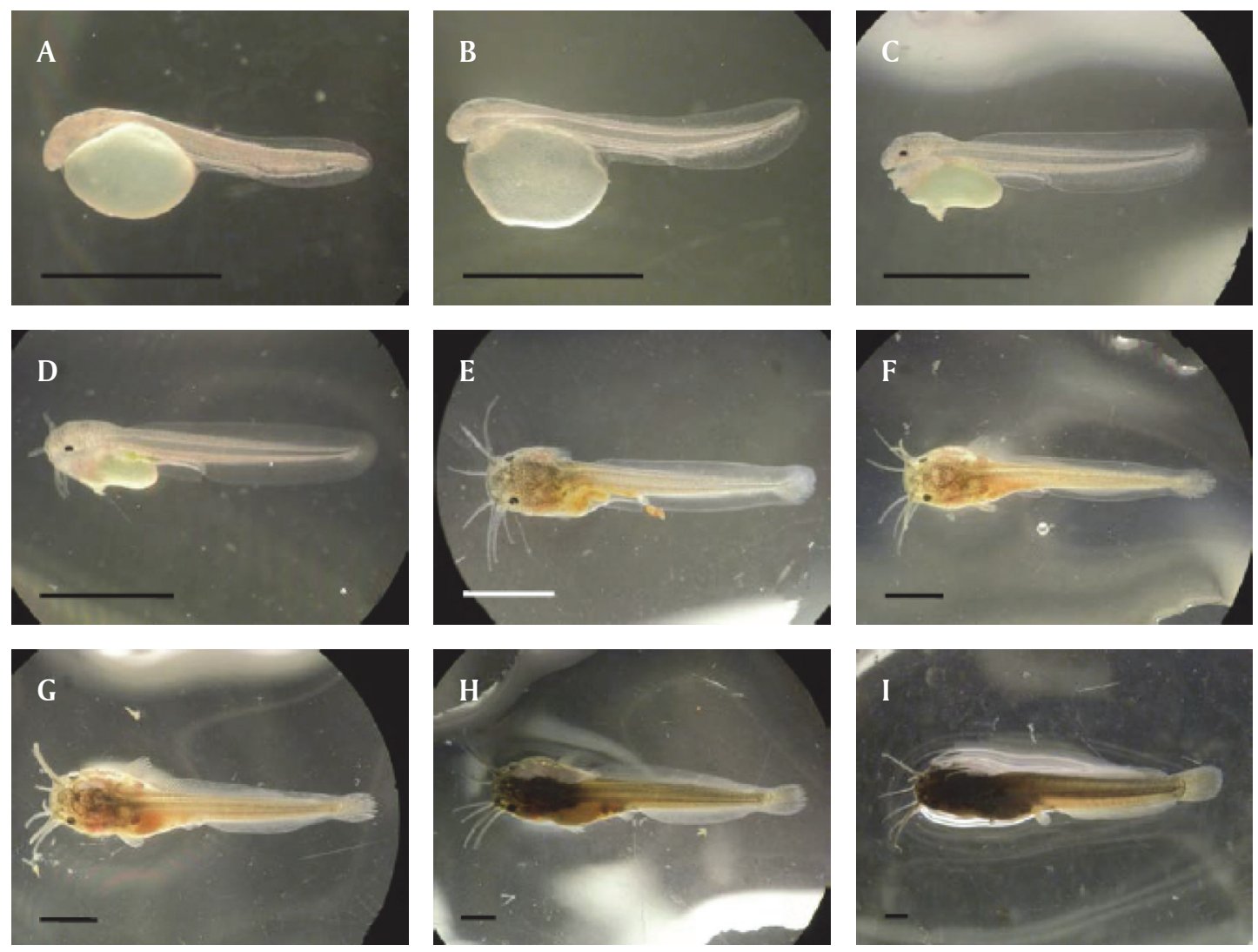

Figure 5. Larval development of the black strain of Egyptian African catfish from hatching until resembled the adults (20.5 days old) (scale bars $=2 \mathrm{~mm}$ )

as demonstrated by Haylor \& Mollah (1995) at water temperature of $20^{\circ} \mathrm{C}-35^{\circ} \mathrm{C}$, which lasted 6.49-1.74 days after hatching. The higher the water temperature, the faster the yolk sac absorption completed.

Adhesive organ at the ventral part of the yolk sac of Egyptian African catfish larvae made the ventral part of the yolk sac attached to each other or sometimes to the bottom of the basket, and their bodies frequently moved. The adhesive organ were also exist in the newly hatched larvae of $H$. longifilis (Legendre \& Teugels, 1991). Upon attached to each other or to substrata, the newly hatched larvae of $C$. gariepinus appeared unable to swim, as reported by Mauguit et al. (2010) that at hatching, the larvae were unable to swim or to make displacements, and the swimming movements were established at 48 hours after hatching. However, based on the observations conducted in the present study, the newly hatched larvae, occasionally and surely when they were disturbed, showed swimming movements, with the most frequent movements were up and down movements, and occasionally showed horizontaly movements. Those movements corresponded to the results observed by Sule et al. (2001) and Mukai et al. (2008). Adhesive organ in the Egyptian African catfish (either red or black) strains disappeared at 40-42 hours after hatching, when the yolk sac was more than $50 \%$ absorbed. At those age, ventral parts of the yolk sacs have already not attached either to each other or to substrata, thus the larvae freely swam, either horizontally or up and down swimming movements, throughout the water bodies. In the previous studies conducted by Sule et al. (2001) and Mukai et al. (2008), those behaviour events were also noticed. Those time were relatively corresponded to the findings of Mauguit et al. (2010) who observed that the swimming movements of $C$. gariepinus larvae commenced at 48 hours after hatching, when the yolk sac almost completely absorbed. Time of those larvae freely swam were relatively in line with the observed first feeding on Artemia sp. nauplii. Furthermore, at those time, the larvae had the completed and functional principal sensory organs as well as the foraging capacities (the eyes, barbels, mouth, intestine, and stomach) (Sule et al., 2001; Mukai et al., 2008; Osman et al., 2008), as also observed in the present study. According to Osman et al. (2008), functionality of the sensory organs and foraging capacities were probably reached 24 hours before complete absorption of the yolk sac, thus active feeding could be initiated, corresponded to the results of the present study. Therefore, when the larvae have already not attached to each other or to the substrata, then the larvae freely swam and distributed troughout the water bodies, indicated that 
exogenous feeding was commenced. Thus, the suitable feed should be given as soon as possible, due to the yolk sac absorption was almost completed. Feeding practiced prior to or around this period influenced the next survival and growth performances of the larvae (Haylor \& Mollah, 1995; Matsumoto et al., 2001).

Pectoral fin buds of both red and black strains larvae appeared since 48 hours after hatching, and the formation of caudal fin rays in both larvae commenced at 84 hours after hatching (Figure 4E and 5E). While, the formation of dorsal and anal fin rays commenced at respectively 114 and 117 hours after hatching, almost in line with the formation of pelvic fins, for which appeared at 120 hours after hatching in the red strain larvae (Figure 4F) and at 125 hours after hatching for the black strain larvae (Figure 5F). During those fins formation, the body colour of both larvae were also darkening, appeared more yellowish in the red strain larvae and more blackish in the black strain one.

Based on the observations conducted in the present study, aerial respiration activities in both red and black strains larvae commenced at 138 hours after hatching (the fifth to sixth day). At fifth day, organs formation of both larvae were relatively completed and both larvae almost resembled the adults, except for dorsal and anal fins for which were still confluent with the caudal fin (Figure 4G and 5G). Besides that, preanal finfold (abdominal keel), which were present since hatching, still exists. In both red and black strains larvae, preanal finfolds were absent since 303 hours after hatching (Figure $4 \mathrm{H}$ and $5 \mathrm{H}$ ). Then, dorsal and anal fins of the black strain larvae perfectly separated from the caudal fin at 480 hours after hatching (Figure 5K), while in the red strain lar- vae commenced at 492 hours after hatching (Figure $4 \mathrm{~K})$. Therefore, larval period of the black strain of Egyptian African catfish at water temperature of $27^{\circ} \mathrm{C}$ $31^{\circ} \mathrm{C}$ was ended from 480 hours after hatching (20 days old), while in the red strain was ended at 492 hours after hatching (20.5 days old). Hecht \& Appelbaum (1987) reported that larval period of $C$. gariepinus in Israel was lasted by days 19 at water temperature of $29 \pm 1.08^{\circ} \mathrm{C}$, slightly similar to that of the present study. Larval period of other Clariidae catfish were also more or less similar to those of $C$. gariepinus. Larvae of $H$. longifilis attained the morphology resembled the adults within 17 days at water temperature of $28^{\circ} \mathrm{C}-30.5^{\circ} \mathrm{C}$ (Legendre \& Teugels, 1991). Larvae of $C$. batrachus in Bangladesh were reported to attain the adult characters within 18 days of rearing at $27^{\circ} \mathrm{C}-28^{\circ} \mathrm{C}$ of water temperature (Hossain et al., 2006), while in India were attained within 20 days at water temperature of $26^{\circ} \mathrm{C}-28^{\circ} \mathrm{C}$ (Dhara \& Saha, 2013).

Based on the total length measurement taken on each 20 red and black strains larvae samples (conducted repeatedly every six hours for the first ten days, then conducted every 24 hours for the subsequent period until their morphology resembled the adults) in the present study suggested that at the same age, which were already initiated at hatching, total length of the red strain larvae tended to be lower than those of the black strain (Figure 6). Those corresponded to the results of previous studies (Iswanto et al., 2013a; 2013c). The fluctuations of growth performances during larval period of both strains of the Egyptian African catfish were observed. Fluctuations of the larval growth performance and even with dip were also reported in the Dutch African catfish $C$. gariepinus and was considered as the common phe-

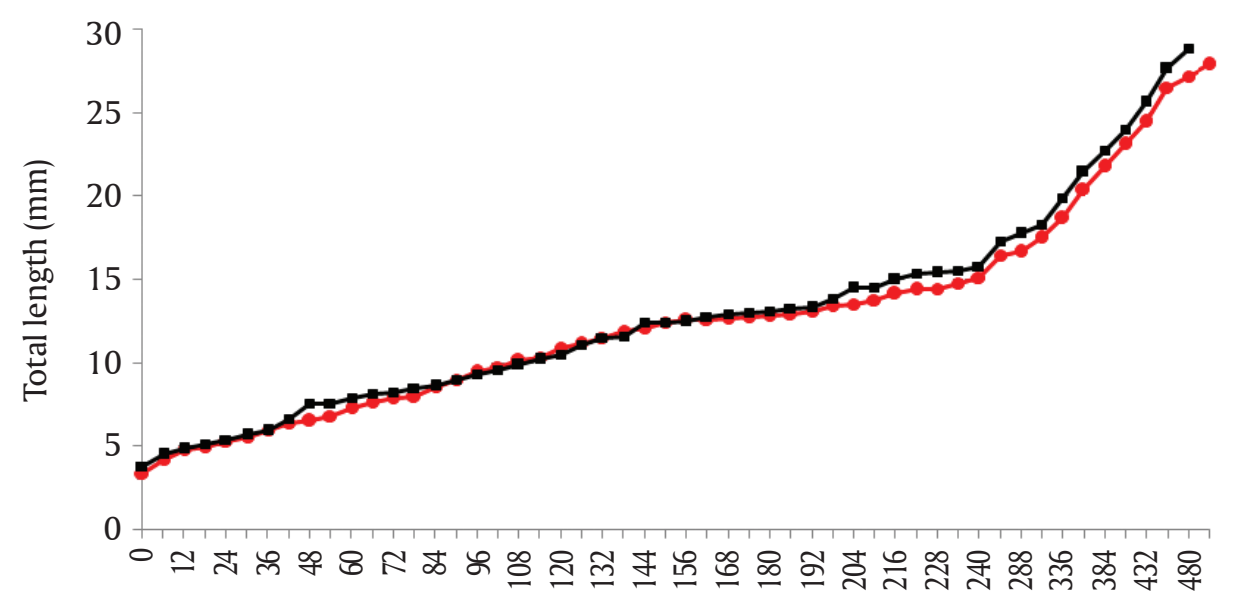

Age (hours after hatching)

Figure 6. Total length development of the red $(\bullet)$ and black (ם) strains larvae of Egyptian African catfish during the larval period 
nomenon in the fish larval growth performances which experienced some transitional morphological (metamorphosis) and physiological developments (Verreth, 1994).

The newly hatched larvae of other $C$. gariepinus strains were relatively bigger than both strains of the Egyptian African catfish. Total length of the newly hatched larvae of $C$. gariepinus in Malawi was $0.47 \pm$ $0.11 \mathrm{~cm}$ (Matsumoto et al., 2001), in the Netherlands ranged 3.6-5.3 mm (Verreth, 1994), in Malaysia averaged 4.2 $\pm 0.2 \mathrm{~mm}$ (Mukai et al., 2008), in Brazil ranged 4.1-5.3 mm (Kipper et al., 2013) and in Nigeria averaged 5.0 $\pm 0.5 \mathrm{~mm}$ (Olaniyi \& Omitogun, 2013). Again, those might be due to the differences of the strain, size, and age of the brooders. Although the larvae of both strains of Egyptian African catfish exhibited relatively smaller size at hatching, at the end of the larval period (about 20-21 days old) total length of both larvae reached $25.80-32.55 \mathrm{~mm}$. Compared to other African catfish strains, those total length were still within the acceptable range. Total length of 21 days old larvae of other African catfish strains, including Sangkuriang, Paiton, and Masamo strains bred during 2012 at RIFB Sukamandi, with the same larval rearing management practices also varied around $1-4 \mathrm{~cm}$ (unpublished data). Growth performances comparison at larval and juvenile stages also suggested that both Egyptian African catfish strains were comparable to Sangkuriang, a superior strain (Bambang et al., 2013a; 2013c). Those results suggested that at early stage, Egyptian African catfish could be considered as a potential $C$. gariepinus strain for aquaculture. However, the growth performances in the next rearing phases still needed to be investigated.

While many publications reported that cannibalism was common in larvae of C. gariepinus (Hecht \& Appelbaum, 1987; Pienaar, 1990; Appelbaum \& Kamler, 2000; Aluko et al., 2001; Baras \& d'Almeida, 2001), in the present study cannibalism was not observed in larvae of Egyptian African catfish reared for 21 days period, either for the red or black strains, thereby resulted in high survival rate, ranged $92 \%-95 \%$. Larval mortalities occurred due to other causes, presumably due to pathogenic infection of unhealthy weak larvae, morphological abnormality condition of the larvae, which died at third and fourth days, and also the feeding incapability (the hunger), assigned by the retained small sizes (no growth in length) of the larvae having exhausted yolk sac, which died at seventh and eighth days. All of those mortalities retained dead larvae with whole complete body condition, suggested that they were not preyed. Also, there was no missing larvae (as referred to the type II cannibalism according to Hecht \& Appelbaum, 1987) nor pieces of body remnant (ussually tail and head as referred to the type I cannibalism according to Hecht \& Appelbaum, 1987) observed during the present study. Even, when several (3-5 larvae) small younger larvae from other Egyptian African catfish brooders, either with same or different colour were introduced into the larval rearing media of both red and black strain larvae of the Egyptian African catfish, there was no cannibalism occurred. Those absences of cannibalism were thought as a result of the relatively uniform size of the larvae (coefficient of variation of the total length during those larval period ranged 1.90\%-6.02\% for the red strain and ranged $1.06 \%-6.01 \%$ in the black strain) and consistent availability of the feed. Results of the studies by Pienaar (1990) and Aluko et al. (2001) suggested that feed availability, stocking density, and size variation affecting cannibalism on the larvae of C. gariepinus. However, results of the present study by using much higher stocking density (100 larvae/ liter) than those of both studies (ranged 0.03-18.18 larvae/liter, recalculated from the data reported by Pienaar, 1990 and Aluko et al., 2001) revealed no cannibalism observed. Baras \& d'Almeida (2001) in their study by using stocking densities of 100 and 200 larvae/liter also concluded that roles of the stocking densities in shaping cannibalism on the larvae of $C$. gariepinus were insignificant. They concluded that size variation was the main factor contributed to shape cannibalism on the larvae of $C$. gariepinus, and even prevailing over the kinship factor. Based on the results of the present study, it was suggested that the low size variation, absence of cannibalism, and high survival rate were special characters of the larvae of Egyptian African catfish. Those characteristics were apparently valuable to be exploited for aquacultural purposes. However, the consistency of those characteristics and whether those were due to genetic factor still needed to be confirmed through forthcoming studies.

\section{CONCLUSION}

Results of the present study revealed that embryonic developments of the red and black strains of Egyptian African catfish were similar. Their larval development were also quite similar, however, both larvae could be distinguished each other based on the pigmentation. At the same age, initiated at hatching, total length of the red strain larvae tended to be lower than those of the black strain.

\section{ACKNOWLEDGEMENT}

Thanks to all of the researcher assistants of Clariidae Catfish Team of Research Institute for Fish Breeding Sukamandi for their technical assistances during broodstock selection and induced spawning activities. 


\section{REFERENCES}

Adebayo, O.T., \& Fagbenro, O.A. (2004). Induced ovulation and spawning of pond-raised African giant catfish, Heterobranchus bidorsalis by exogenous hormones. Aquaculture, 242, 229-236.

Adriaens, D. (1998). On how a larva become an adult catfish, a functional morphological approach to the cranial ontogeny of the African catfish, Clarias gariepinus (Siluriformes, Clariidae), Part I Text. Doctoral Thesis. Faculteit Watenschappen, Universiteit Gent. Gent. Belgium, 240 pp.

Adriaens, D., \& Vandewalle, P. (2003). Embryonic and larval development in catfishes. In Arratia, G., Kapoor, B., Chardon, M., \& Diogo, R. (Eds.). Catfishes. Science Publisher, Inc. USA, p. 639-666.

Aluko, P.O., Nlewadim, A.A., \& Aremu, A. (2001). Observations of fry cannibalism in Clarias gariepinus. Journal of Aquatic Sciences, 16, 1-6.

Appelbaum, S., \& Kamler, E. (2000). Survival, growth, metabolism and behaviour of Clarias gariepinus (Burchell 1822) early stages under different light conditions. Aquacultural Engineering, 22, 269-287.

Baras, E., \& d'Almeida, A.F. (2001). Size heterogeneity prevails over kinship in shaping cannibalism among larvae of sharptooth catfish Clarias gariepinus. Aquatic Living Resources, 14, 251-256.

Cheah, S.H., Siraj, S.S., \& Ang, K.J. (1990). A preliminary study on induced spawning of the catfish Clarias batrachus (Linnaeus) in Malaysia. Pertanika, 13(1), 63-66.

Dhara, K., \& Saha, N.C. (2013). Controlled breeding of Asian catfish Clarias batrachus using pituitary gland extracts and ovaprim at different temperatures, latency periods and their early development. Journal of Aquaculture Research and Development, 4(4), 186. doi:10.4172/2155-9546.1000186.

Haylor, G.S., \& Mollah, M.F.A. (1995). Controlled hatchery production of African catfish, Clarias gariepinus: the influence of temperature on early development. Aquatic Living Resources, 8, 431-438.

Hecht, T., \& Appelbaum, S. (1987). Notes on the growth of Israeli sharptooth catfish (Clarias gariepinus) during the primary nursing phase. Aquaculture, 63, 195-204.

Hoffman, L.C., \& Prinsloo, J.F. (1995). Genetic and nutritional influence on the total lipid fatty acid profile of Clarias gariepinus muscle. Aquatic Living Resources, 8, 415-421.

Hoffman, L.C., Prinsloo, J.F., Theron, J., \& Casey, N.H. (1995a). The genotype influence of four strains of Clarias gariepinus on the larvae body proximate, total lipid fatty acid, amino acid and mineral compositions. Comparative Biochemistry and Physiology,
110B(3), 589-597.

Hoffman, L.C., Prinsloo, J.F., Theron, J., \& Casey, N.H. (1995b). A chemical comparison between the golden and normal coloured strains of the African sharptooth catfish, Clarias gariepinus (Burchell 1822). Journal of Applied Ichthyology, 11, 71-85.

Hogendoorn, H., \& Vismans, M.M. (1980). Controlled propagation of the African catfish, Clarias lazera (C\&V). II. Artificial reproduction. Aquaculture, 21, 3953.

Hossain, Q., Hossain, M.A., \& Parween, S. (2006). Artificial breeding and nursery practices of Clarias batrachus (Linnaeus, 1758). Scientific World, 4(4), 32-37.

Iswanto, B., Suprapto, R., Marnis, H., \& Imron. (2013a). Growth performance of a red strain of Egyptian African catfish (Clarias gariepinus Burchell, 1822) at larval rearing and nursery phases. Paper presented in: Forum Inovasi Teknologi Akuakultur 2013, 12-13 Juni 2013. Mataram, Indonesia, 15 pp. (in Indonesian).

Iswanto, B., Suprapto, R., Marnis, H., \& Imron. (2013b). Total length-weight relationship and condition factor of a red Egyptian African catfish (Clarias gariepinus Burchell, 1822) strain at the market size. Paper presented in: Seminar Nasional Perikanan Hasil Penelitian Perikanan dan Kelautan Tahun 2013. Jakarta, 9 pp. (in Indonesian with English abstract).

Iswanto, B., Suprapto, R., Marnis, H., Ridzwan, N.S., \& Imron. (2013c). Larval growth performance of a red strain of Egyptian African catfish (Clarias gariepinus Burchell, 1822) strain merah. Prosiding Seminar Nasional Perikanan Hasil Penelitian Perikanan dan Kelautan Tahun 2012. p. 42-48. (in Indonesian with English abstract).

Kamler, E. (2005). Parent-egg-progeny relationships in teleost fishes: an energetic perspectives. Reviews in Fish Biology and Fisheries, 15, 399-421.

Kamler, E., Szlaminska, M., Kuczynski, M., Hamackova, J., Kouril, J., \& Dabrowski, R. (1994). Temperature-induced changes of early development and yolk utilization in the African catfish Clarias gariepinus. Journal of Fish Biology, 44, 311-326.

Kipper, D., Taguti, T.L., Bialetzki, A., Makrakis, M.C., Baumgartner, G., \& Sanches, P.V. (2013). Early ontogeny of Clarias gariepinus (Siluriformes, Clariidae) and aspects of its invasion potential in natural freshwater environments. Maringa, 35(3), 411418.

Korzelecka-Orkisz, A., Smaruj, I., Pawlos, D., Robakowski, P., Tanski, A., Szulc, J., \& Formicki, K. (2010). Embryogenesis of the stinging catfish, Heteropneustes fossilis (Actinopterygii: Siluriformes: 
Heteropneustidae). Acta Ichthyologica et Piscatoria, 40(2), 187-197.

Legendre, M. (1986). Seasonal changes in sexual maturity and fecundity, and HCG-induced breeding of the catfish, Heterobranchus longifilis Val. (Clariidae), reared in Ebrie Lagoon (Ivory Coast). Aquaculture, 55, 201-213.

Legendre, M., Linhart, O., \& Billard, R. (1996). Spawning and management of gametes, fertilized eggs and embryos in Siluroidei. Aquatic Living Resources, 9, 59-80.

Legendre, M., \& Teugels, G.G. (1991). Development and thermal tolerance of eggs in Heterobranchus longifilis, and comparison of larval developments of H. longifilis and Clarias gariepinus (Teleostei, Clariidae). Aquatic Living Resources, 4, 227-240 (in French with English abstract).

Lenormand, S., Slembrouck, J., Pouyaud, L., Subagja, J., \& Legendre, M. (1998). Evaluation of hybridisation in five Clarias species (Siluriformes, Clariidae) of African (C. gariepinus) and Asian origin (C. batrachus, C. meladerma, C. nieuhofii, and C. teijsmanni). In Legendre, M., \& Parisele, A. (Eds.). The Biological Diversity and Aquaculture of Clariid and Pangasiid Catfishes in South-East Asia. Proceeding of The Mid-Term Workshop of the Catfish Asia Project, 11-15 May 1998. Cantho, Vietnam, p. 195-209.

Matsumoto, S., Morioka, S., \& Kumagai, S. (2001). Development of African catfish Clarias gariepinus larvae during transitional phase between endogenous and exogenous energy intake. In Weyl, O.L.F., \& Weyl, M.V. (Eds.). Proceeding of the Lake Malawi Fisheries Management Symposium, 4-9 June 2001. Lilongwe, Malawi, p. 225-232.

Mauguit, Q., Gennotte, V., Becco, C., Baras, E., Vandewalle, N., \& Vandewalle, P. (2010). Ontogeny of swimming movements in the catfish Clarias gariepinus. The Open Fish Science Journal, 3, 16-29.

Mekkawy, I.A.A., \& Osman, A.G.M. (2006). Ultrastructural studies of the morphological variations of the egg surface and envelopes of the African catfish Clarias gariepinus (Burchell, 1822) before and after fertilisation, with a discussion of the fertilisation mechanism. Scientia Marina, 70(S2), 23-40.

Mollah, M.F.A., \& Tan, E.S.P. (1983). HCG-induced spawning of the catfish, Clarias macrocephalus (Gunther). Aquaculture, 35, 239-247.

Mukai, Y., Tuzan, A.D., Lim, L.S., Wahid, N., Raehanah, M.S.S., \& Senoo, S. (2008). Development of sensory organs in larvae of African catfish Clarias gariepinus. Journal of Fish Biology, 73, 1648-1661.

Olaniyi, W.A., \& Omitogun, O.G. (2013). Stages in the early and larval development of African catfish Clarias gariepinus (Teleostei, Clariidae). Zygote, p. 1-17. doi:10.1017/S0967199413000063.

Omeji, S., Obande, R.A., \& Oyaje, J. (2013). Intra-specific hybridization of local and exotic Clarias gariepinus. International Journal of Modern Biological Research, 1, 35-41.

Onyia, L.U., Ladu, B.M.B., \& Olufeagba, S.O. (2012). Embryogenetic studies of intra-specific Clarias anguillaris hybrid: Implication on genetic manipulation. International Journal of Biochemistry and Biotechnology, 1(6), 170-174.

Osman, A.G.M., Wuertz, S., Mekkawy, I.A., Verreth, I.A., \& Kirschbaum, F. (2008). Early development of the African catfish Clarias gariepinus (Burchell, 1822), focusing on the ontogeny of selected organs. Journal of Applied Ichthyology, 24, 187-195.

Oyelese, O.A. (2006). Water temperature a determinant of fertilization and hatchability rates in artificially induced breeding of Clarias gariepinus (Teleostei: Clariidae). Research Journal of Biological Sciences, 1(1-4), 83-87.

Pienaar, A.G. (1990). A study of coeval sibling cannibalism in larval and juvenile fishes and its control under culture conditions. MSc Thesis. Rhodes University, $162 \mathrm{pp}$.

Prinsloo, J.F., \& Schoonbee, H.J. (1989). Notes on comparison of the catchability and growth of a red and normal variety of the sharptooth catfish Clarias gariepinus (Burchell) stocked together in fish production ponds (Short Communication). Water SA, 15(3), 191-194.

Prinsloo, J.F., Schoonbee, H.J., \& Theron, J. (1989a). The use of a red strain of the sharptooth catfish Clarias gariepinus (Burchell) in the evaluation of cannibalism amongst juveniles of this species. Water SA, 15(3), 179-184.

Prinsloo, J.F., Schoonbee, H.J., \& van der Walt, I.H. (1989b). Production studies with red and normal varieties of the sharptooth catfish Clarias gariepinus (Burchell) using a mixture of minced fish, bakery-floor sweepings and a formulated pelleted diet. Water SA, 15(3), 185-190.

Prinsloo, J.F., Schoonbee, H.J., \& Hoffman, L.C. (1990). A comparison of the fecundity of two strains of the sharptooth catfish Clarias gariepinus. South African Journal of Wildlife Resources, 20(3), 100-103 (abstract).

Puvaneswari, S., Marimuthu, K., Karuppasamy, R., \& Haniffa, M.A. (2009). Early embryonic and larval development of Indian catfish, Heteropneustes fossilis. EurAsian Journal of BioSciences, 3, 84-96.

Riehl, R., \& Appelbaum, S. (1991). A unique adhesion apparatus on the eggs of the catfish Clarias garie- 
pinus (Teleostei, Clariidae). Japanese Journal of Ichthyology, 38(2), 191-197.

Riehl, R., \& Patzner, R.A. (1998). Minireview: The modes of egg attachment in teleost fishes. Italian Journal of Zoology, 65(S1), 415-420.

Rognon, X., Teugels, G.G., Guyomard, R., Galbusera, P., Andriamanga, M., Volkcaert, F., \& Agnese, J.F. (1998). Morphometric and allozyme variation in the African catfishes Clarias gariepinus and $C$. anguillaris. Journal of Fish Biology, 53, 192-207.

Sule, O.D., Adikwu, I.A., \& Aluko, P.O. (2001). Embryonic development in Clarias gariepinus under laboratory conditions. Proceeding of the 16th Annual Conference of the Fisheries Society of Nigeria (FISON). Maiduguri, Nigeria, 4-9 November 2001. p. 266270.

Tan-Fermin, J.D. (2003). Catfish aquaculture. SEAFDEC Asian Aquaculture, October-December, XXV (1), 13.
Teugels, G.G. (1998). Intra-and interspecific morphometric variation in Clarias gariepinus and $C$. anguillaris (Siluroidei, Clariidae). In Agnese, J.F. (Ed.). Genetics and Aquaculture in Africa. Actes du colloque Génétique et aquaculture en Afrique, Abidjan, $1^{\text {er-4 }}$ avril 1997. Institut Francais de Recherche Scientifique pour le Developpement en Cooperation. Paris, France. Pp. 241-248.

Verreth, J. (1994). Nutrition and related ontogenetic aspects in larvae of the African catfish, Clarias gariepinus. DSc Thesis. Department of Fish Culture and Fisheries, Wageningen Agricultural University. Wageningen, The Netherlands. $205 \mathrm{pp}$.

Wang, W.M., K. Abbas and A.S. Yan. (2006). Embryonic development of Pelteobagrus fulvidraco (Richardson, 1846). Chinese Journal of Oceanology and Limnology 24(4): 378-383. 